\title{
Black carbon aerosols from the coal seam of eastern India: A real-time analysis with statistical validation
}

\author{
Ahmad Nawaz ${ }^{1}$, Siddharth Singh ${ }^{2}$ and Pichiah Saravanan ${ }^{1} *$ @ \\ ${ }^{1}$ Environmental Nanotechnology Laboratory, Indian Institute of Technology (Indian School of Mines), \\ Dhanbad, Jharkhand 826004 , India. \\ ${ }^{2}$ Natural Resources and Environment Management, CSIR-Central Institute of Mining and Fuel Research, \\ Barwa Road, Dhanbad, Jharkhand 826 015, India. \\ *Corresponding author. e-mail: saravananpichiah@iitism.ac.in
}

MS received 1 May 2018; revised 23 October 2018; accepted 20 December 2018; published online 9 May 2019

Underground coal seam fire is one of the serious problems caused by coal mining activities. Hence, the present study is focused on investigating the potential emission of black carbon (BC) and its dispersion from the fire-affected area located in the Jharia coal field, Dhanbad district of the Jharkhand state of India. The real-time BC concentration measurements in the active fire area and the adjacent neighbouring urban area were studied and reported. Results showed an average concentration of BC was $12.54 \mu \mathrm{g} \mathrm{m}^{-3}$ in the fumes/smokes emitting from the surface cracks and vents at the fire-affected zone. The continuous probability distribution functions, i.e., lognormal, gamma and Weibull, were used to fit the BC data individually, and among these lognormal fits, the best were for the medium-range values. Furthermore, the robustness of the obtained $\mathrm{BC}$ concentration was also explained by these models. All fitness was in good agreement, in the studied area, with the coefficient of regression ranging between 0.84 and 0.96. Both the experimental and predicted results clearly indicated the contribution of the BC that discharged from the coal seam fire as a source of particulate pollutant. Spatial modelling was also performed to validate the experimental consistency of $\mathrm{BC}$ concentration while the model was in good agreement with the underground coal fire zone as compared to the rest.

Keywords. Black carbon; coal seam fire; dispersion; goodness of fit; lognormal; variogram.

\section{Introduction}

In general, the coal stratum fire typically occurs when the coal stratum is continually exposed to an ambient atmosphere (US Department of Energy 1993; Walker 1999; Bell et al. 2001; Heffern and Coates 2004; Stracher 2004; Pone et al. 2007). The fire is initiated with the incessant adsorption of oxygen from the atmosphere by the unadorned portion of the coal (Kuenzer and Stracher 2012). The combustion results in the release of an enormous amount of heat as a byproduct since the reaction is of exothermic nature. Thus, the released heat energy is engulfed within the coal seam resulting from the emission of the first smoke from the cracks of the Earth's surface (Limacher 1963; Rein 2011). Furthermore, when the temperature reaches the critical ignition point

Supplementary material pertaining to this article is available on the Journal of Earth System Science website (http://www. ias.ac.in/Journals/Journal_of_Earth_System_Science). 
$\left(80-130^{\circ} \mathrm{C}\right)$, the coal tends to smoulder and burn with flare and such happenings take place during the preliminary stage of the coal seam fire phenomenon (Taraba and Michalec 2011). The coal seam fire in the Jharia coal field (JCF), India was first identified in 1916, the period when the first traditional mining activities were initiated. In the initial days, there was little or no panic situation, but later, the situation grew to be life-threatening over the years and reached saturation by spreading the fire zone to $450 \mathrm{~km}^{2}$ (Prakash 2007; Sarkar et al. 2007). Similar cases were reported in Australia, China, USA and Indonesia where seam fires are uncontrollable even after half a century (Ellyett and Fleming 1974; Nolter and Vice 2004; Stracher 2004; Zhang et al. 2004; Sharygin et al. 2009).

In the present scenario, India has the most coal seam fires in the world, with regard to both magnitude and multitude due to the richest natural deposition of coal. In recent years, the country's coal production escalated and reached $7.7 \%$ of the global share (World Coal Association 2012), thus paving the path to an increase in such coal fires. According to a survey by Bharat Coking Coal Limited (BCCL), in 2008, it was estimated that there were at least 67 coal mines in the vicinity of the JCF affected by the fire (BCCL 2008). The incomplete combustion of fossil fuels and the burning of biomass and other fuels result in major by-products such as BC (Bond et al. 2013). It is known that the burning of coal emits aerosol BC that is typically of $50 \mathrm{~nm}$ in diameter (Penner et al. 1993; Wang et al. 2015). The residence time of such submicron carbonaceous particles in the atmosphere varies from days to weeks and hence they spread over hundreds to thousands of kilometres (Wolff 1981; Parungo et al. 1994; Cooke and Wilson 1996; Liousse et al. 1996). Eventually, the population nearby the coal mines is highly exposed to the $\mathrm{BC}$ emission, posing a high risk of health hazards. The BC aerosols easily enter the human body via the respiratory system and reach the internal organs such as the lungs and the liver through the blood, causing serious problems (Highwood and Kinnersley 2006). Pulmonary diseases, i.e., asthma and black lung, and cardiovascular diseases are some very common problems around the coal mining area (Banks et al. 1998; Finkelman et al. 2002; Yudovich and Ketris 2005; Hendryx and Ahern 2008; Hendryx 2009; Wu and Liu 2011).

This underground seam fire at JCF is a centuryold activity which gradually forced the relocation of human settlements. The overall population density is relatively high in the periphery of the area, since most of the locals' livelihood depends directly or indirectly on the coal mining activity. To date, several efforts are being made by the local administration to relocate the affected communities adjacent to the coal seam fire. However, the authorities face discrepancy due to the social prevalence of the dwelling community (Magnier 2012). Moreover, it was clear that the prolonged emission and dispersion of $\mathrm{BC}$ concentration was the root cause of air-borne diseases such as pneumoconiosis, silicosis and dust-related diffuse fibrosis, and thus dislocated the community (Christian et al. 1979). These circumstances clarified the vitality to know the presence of $\mathrm{BC}$ concentration in the local atmosphere. Hence, the present study aimed at investigating the real-time emission of $\mathrm{BC}$ concentration that takes place directly from the cracks of JCF. The dispersion on the neighbouring locality was also studied by measuring the $\mathrm{BC}$ concentration. All obtained experimental findings were validated for their consistency through probability and discrete distribution function. This kind of work is of foremost importance and has not been reported in the past.

\section{Study area}

The study area, the JCF, is located in the jurisdiction of Dhanbad district, eastern part of the Jharkhand state of India. The mining activities in the study area are more than a century-old and the representation of the seam fire is shown in figure 1 . The district falls below the Indo-Gangetic plain (IGP) and has a total area of $2040 \mathrm{~km}^{2}$ (Singh and Mondal 2008). The demographic information as per the 2011 census is as follows: The total population consists of 2,684,487 people; among them, the rural population accounts for $1,124,093$ and the urban population comprises $1,560,394$ people with a density of 1285 persons $\mathrm{km}^{-2}$ (Census of India 2011).

The experiment pertaining to the $\mathrm{BC}$ concentration measurement was carried out at three locations, namely X, Y and Z areas as follows: The underground coal seam mine with the fire affected zone is denoted as the $\mathrm{X}$ area; a $500 \mathrm{~m}$ away from the west of this fire affected area is denoted as the $\mathrm{Y}$ area and, finally, the urban area of Dhanbad city is denoted as the $\mathrm{Z}$ area. The geographical description of the study area is shown in figures S1 and S2 and table 1 , respectively, along with the sampling period. 


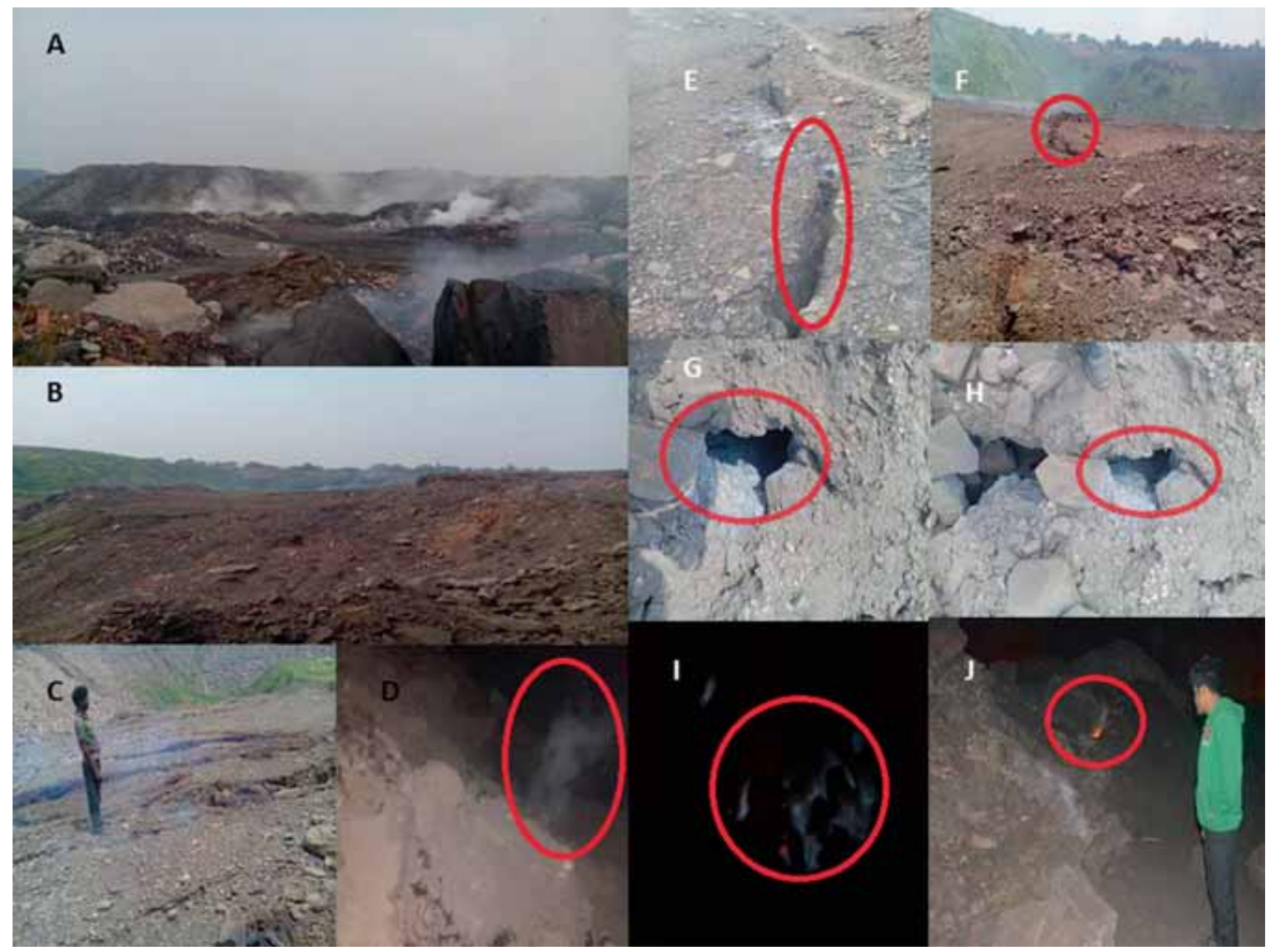

Figure 1. Sampling location and scenario of the underground coal fire in Jharia (X area). [Landscape of X area (a and $\mathbf{b})$; open-flame site $(\mathbf{c})$; smoking surface vent $(\mathbf{d})$; non-smoking surface vents (e and $\mathbf{f})$; smoking surface vents (g and $\mathbf{h})$ and open fire $(\mathbf{i}$ and $\mathbf{j})$ ].

Table 1. Geographical information of the study area with the sampling period.

\begin{tabular}{lcccccc}
\hline $\begin{array}{l}\text { Study } \\
\text { area }\end{array}$ & City & Latitude & Longitude & $\begin{array}{c}\text { Altitude } \\
(\mathrm{msl})\end{array}$ & Sampling period & Time \\
\hline $\mathrm{X}$ area & Jharia & $23^{\circ} 45^{\prime} 29.64^{\prime \prime} \mathrm{N}$ & $86^{\circ} 25^{\prime} 05.73^{\prime \prime} \mathrm{E}$ & 201 & Sep-Oct 2015 (39 days) & $6: 00 \mathrm{AM}-6: 00$ PM \\
$\mathrm{Y}$ area & Jharia & $23^{\circ} 45^{\prime} 13.44^{\prime \prime} \mathrm{N}$ & $86^{\circ} 25^{\prime} 03.43^{\prime \prime} \mathrm{E}$ & 206 & Sep-Oct 2015 (22 days) & $6: 00$ AM-6:00 PM \\
$\mathrm{Z}$ area & Dhanbad & $23^{\circ} 47^{\prime} 43.43^{\prime \prime} \mathrm{N}$ & $86^{\circ} 25^{\prime} 37.34^{\prime \prime} \mathrm{E}$ & 222 & March 2016 (30 days) & $6: 00$ AM-6:00 PM \\
\hline
\end{tabular}

The $\mathrm{X}$ area which is the landscape part is shown in figure 1(b). The underground crust of the central area is severely affected by the coal seam fire that discharged heavy black smoke into the atmosphere (near-surface) and is shown in figure 1(a). The area also consists of both smoking (figure $1 \mathrm{~d}$, g and $\mathrm{h}$ ) and non-smoking surface vents (figure 1e and f) and cracks with several small scattered exposed flame spots (figure 1c). Amid the southeast of the peripheral and the central area, a 20-m-deep pit has a visible flare excavated by the board and pillar method. Furthermore, an abandoned giant coal pillar spread with a layer of stones and debris lies half way to the proximity of the fire zone (figure 1f). Flaring fires can be seen on the surface of the central $\mathrm{X}$ area and at the bottom of the pit (see figure $1 \mathrm{i}$ and $\mathrm{j}$ ). There are many different types of flattened surfaces in the peripheral area, free of cracks and vents, while the surrounding of the periphery is adhered to the raw materials and the coal washery is owned by Coal India Limited (CIL). 
Table 2. Meteorological data of the study area.

\begin{tabular}{lccc}
\hline & Sep & Oct & March \\
Sampling period & 2015 & 2015 & 2016 \\
\hline Humidity (\%) & 64 & 55 & 70 \\
Rainfall (mm) & 0 & 0 & 0 \\
Ambient temp. $\left({ }^{\circ} \mathrm{C}\right)$ & 32.8 & 28.9 & 35.2 \\
Emission temp. $\left({ }^{\circ} \mathrm{C}\right)$ & 58 & 56.9 & - \\
Emission velocity $\left(\mathrm{m} \mathrm{s}^{-1}\right)$ & 2.1 & 1.9 & - \\
\hline
\end{tabular}

The second sampling point designated as the $\mathrm{Y}$ area is situated about $0.5 \mathrm{~km}$ away to the north of the $\mathrm{X}$ area within the same mining region. This area was abandoned because of the intense fire and it was once used for eco-restoration (see figure S3). As a result of the active coal fire, the surface is compressed and flattened with the visible presence of coal ash lying haphazardly. The moisture present at the bottom of the ash acts as binder and makes it hard over a period of time. This hard and tough surface restricts the smoke escaping into the atmosphere and reduces the particulate matter. However, the emission of smoke from the uneven surface in the $\mathrm{Y}$ area confirms the intense activity of the underground fire and propagates in the south direction with smoke and a few open fires.

The final sampling point is the urban area of Dhanbad district (the $\mathrm{Z}$ area) occupied by the urban community. Apart from coal mines, there are a few active thermal power plants located adjacent within $\sim 90 \mathrm{~km}$ from the sampling location. The basic meteorological information of the study area is provided in table 2 . The daily recorded value is presented as an average value of each month. The other meteorological conditions such as wind speed variation and its direction in the mining area are shown in figure 2( $\mathrm{a}$ and $\mathrm{b}$ ), respectively. It was clearly observed that the wind speed varied with a mean value of $0.56 \mathrm{~m} \mathrm{~s}^{-1}$, and a standard deviation of 0.59 . The coal samples obtained from both the $\mathrm{X}$ and $\mathrm{Y}$ areas were analysed for their composition through proximate analysis and the results are presented in table 3 .

\section{Materials and methods}

\subsection{Analytical method and sampling procedure}

The near surface atmospheric $\mathrm{BC}$ concentrations were measured during the post-monsoon period, i.e., September-October 2015 and March 2016. The measurement was carried out with the support of a portable real-time in-situ aethalometer (AE31-Magee scientific, USA) with a minimum detection limit of $2 \mathrm{ng} \mathrm{m}^{-3}$ of $\mathrm{BC}$ concentration in ambient air. The calibration of the instrument was carried out on a regular basis prior to the actual experiment. The experimental setup consists of an inlet tube made of Teflon exposed to the smoke emitted from the cracks and vents and is schematically represented in figure 3 . The tube inlet was fabricated for ease of handling at a proper position and height throughout the experiment. Other supplementary instruments comprise
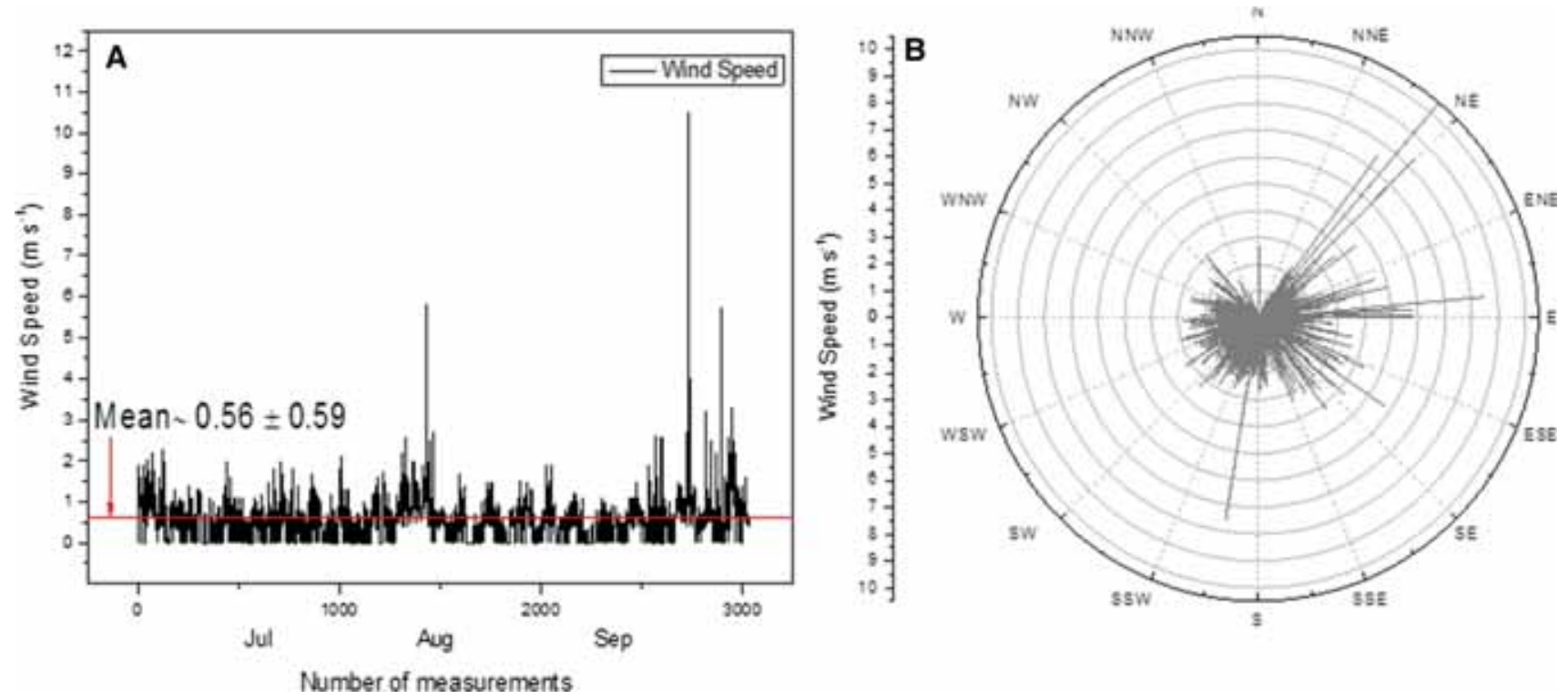

Figure 2. (a) Seasonal pattern of wind speed and (b) wind direction in Dhanbad city in 2015. 
Table 3. Proximate analysis of the coal sample.

\begin{tabular}{lllllll}
\hline $\begin{array}{l}\text { Sampling } \\
\text { area }\end{array}$ & $\begin{array}{c}\text { Moisture } \\
(\%)\end{array}$ & $\begin{array}{l}\mathrm{Ash} \\
(\%)\end{array}$ & $\begin{array}{l}\mathrm{FC}^{*} \\
(\%)\end{array}$ & $\begin{array}{l}\mathrm{VM}^{\dagger} \\
(\%)\end{array}$ & $\begin{array}{l}\mathrm{C}^{\ddagger} \\
(\%)\end{array}$ & $\begin{array}{l}\mathrm{S}^{\text {ฯ }} \\
(\%)\end{array}$ \\
\hline $\mathrm{X}$ & 0.94 & 17.49 & 60.64 & 19.92 & 70.17 & 0.175 \\
$\mathrm{Y}$ & 1.27 & 16.38 & 57.06 & 25.28 & 84.88 & 0.135 \\
\hline
\end{tabular}

${ }^{*}$ Fixed carbon, ${ }^{\dagger}$ Volatile matter.

${ }^{\ddagger}$ Carbon, ${ }^{\top}$ Sulphur.

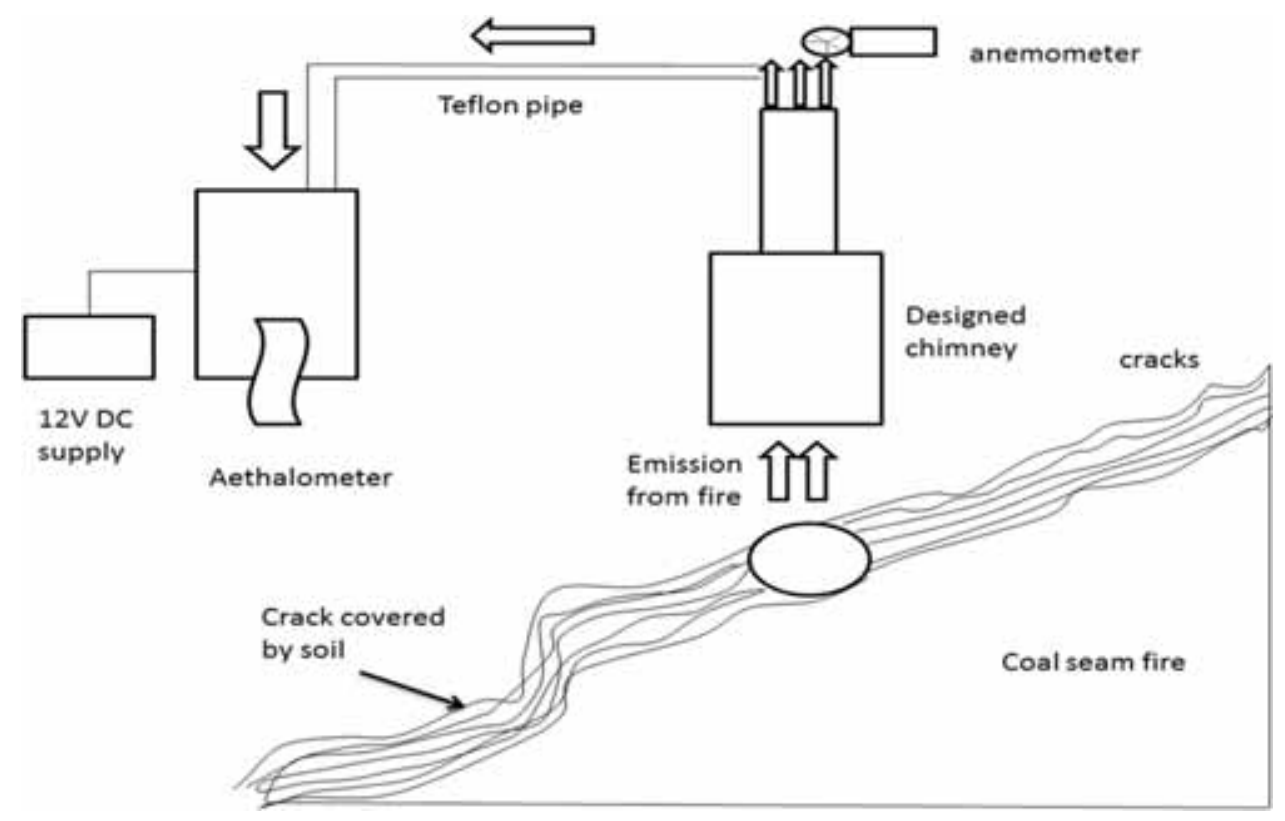

Figure 3. Schematic diagram of the BC sampling process.

a digital anemometer (AM-4201, Lutron, Taiwan), an infrared surface temperature analyser (TW7001, ifm electronic gmbh, Germany) and a highresolution mobile global positioning system. The emission velocity of the fumes was measured by employing a chimney designed for the purpose and is shown in figure 3 .

Direct measurements were carried out at the cracks and vents of the sampling location with the support of a chimney designed and fabricated for the purpose. The chimney was laid on the cracks or vents with the inlet of the aethalometer tube placed at $0.15 \mathrm{~m}$ from the surface level. Clearance was maintained to avoid the high surface temperature prevalent at the sampling point. The data were recorded for an interval of $5 \mathrm{~min}$, and the measurement lasted for 90 min with 18 measurements per spot overall. The time series illustration of the measurements at spot $G$ is shown in figure 4 . A square network, of $200 \times 200 \mathrm{~m}$ in the $\mathrm{X}$ area and $100 \times 100 \mathrm{~m}$ in the $\mathrm{Y}$ area, covering the core and the surrounding area of the studied region, is marked for sampling. The real-time measurements of $\mathrm{BC}$ were recorded at each spot from the ground surface at a height of $1.5 \mathrm{~m}$ above and the mean BC calculated at each spot was mapped using ESRIs ArcGIS 9.3. In the urban area of Dhanbad, i.e., the $\mathrm{Z}$ area, due to the continuous infrastructure of development projects, the sampling was subjected alongside the road as shown in figure S4. This was achieved by placing the aethalometer on the rear of a car cruising at a velocity of $15 \mathrm{~km} \mathrm{~h}^{-1}$ and the inlet of the tube facing outside the rear side of the window. The $\mathrm{BC}$ concentration was measured at an equal linear interval along the roadside with each sampling at $200 \mathrm{~m}$ in a continuous manner and the average BC concentration was plotted with ArcGIS 9.3. Variogram modelling was performed with the help of ArcMap10.0.

For the statistical analysis and modelling, BC data were taken as the average of $1 \mathrm{~h}$ and solved with the support of SPSS 16.0 and Minitab 17.0. All reported BC concentration was focused only near the coal seam fire (cracks and vents) and the direct measurement at the open-flame sites was not 


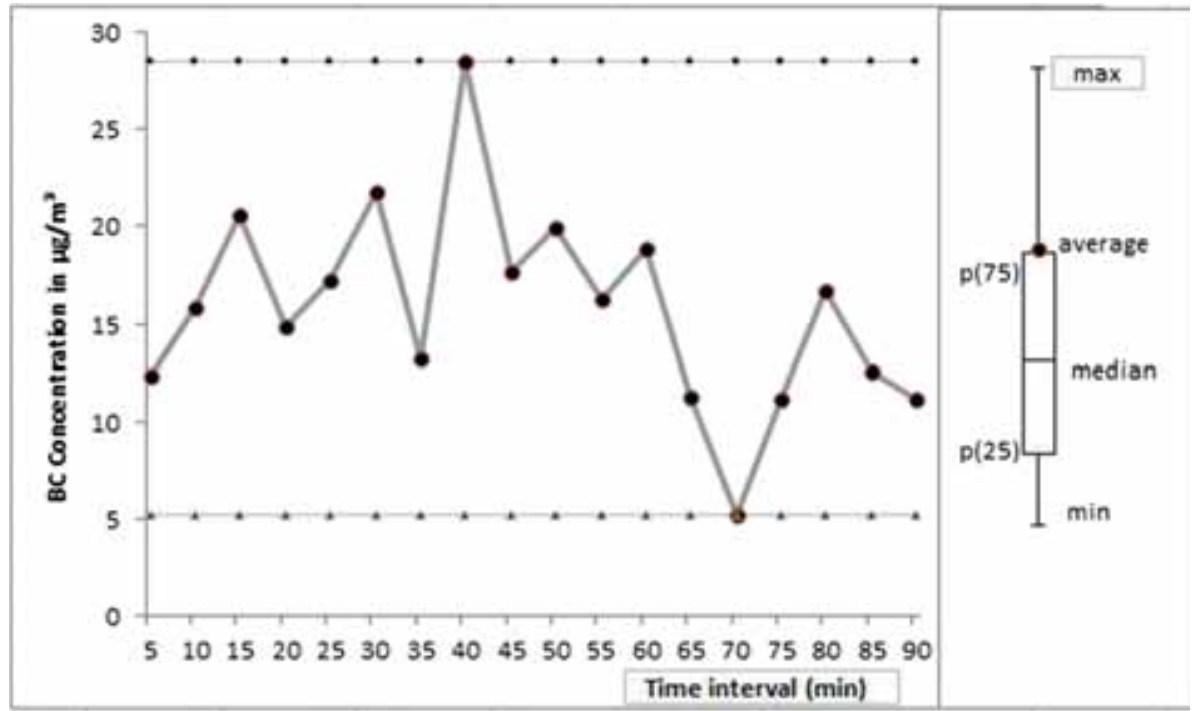

Figure 4. Time series plot of BC concentration.

considered owing to high flame temperature i.e., $800-1000^{\circ} \mathrm{C}$.

\subsection{Statistical analysis}

The theoretical distribution functions: lognormal, gamma and Weibull were adopted in validating the hourly average BC concentrations. The following equations provided the probability density functions (PDFs) of the mathematical expression of these distributions as follows (Weglarczyk 2010):

Lognormal distribution:

$$
f_{1}(x)=\frac{1}{x \sigma \sqrt{2 \pi}} \exp \left[-\frac{1}{2}\left(\frac{\ln (x)-\mu}{\sigma}\right)^{2}\right],
$$

where $\sigma$ and $\mu$, respectively, are the scale and location parameters.

Gamma distribution:

$$
f_{\mathrm{g}}(x)=\frac{\alpha^{\lambda}}{\Gamma(\lambda)} x^{\lambda-1} \exp (-\alpha x)
$$

where $\alpha, \lambda>0$ and $\Gamma(\lambda)$ is the Euler's gamma function:

Weibull distribution:

$$
f_{\mathrm{w}}(x)=\beta \alpha^{\beta}(x)^{\beta-1} \exp \left[-(\alpha x)^{\beta}\right],
$$

where $\alpha>0$ is the scale parameter and $\beta>0$ is the shape parameter.

Validation of the theoretical PDFs was verified by the goodness of fit, and for this purpose, the cumulative empirical distribution function (EDF) defined by D'Agostino and Stephens (1986) was calculated first:

$$
\begin{aligned}
F_{(n)}(x)= & \frac{\text { Number of observations } \leq x}{n}, \\
& -\propto<x<\propto .
\end{aligned}
$$

The analysis was based on the difference between the EDFs and the cumulative lognormal $f_{1}(x)$, gamma $f_{\mathrm{g}}(x)$ and the Weibull $f_{\mathrm{w}}(x)$ distributions. The supremum statistics introduced by the Kolmogorov and Smirnov test and the AndersonDarling $A^{2}$ statistic were also performed.

The proficiency of three theoretical distributions was ignored in order to model the empirical data. The commonly adopted statistical modelling for atmospheric sciences was also evaluated with a set of performance indicators (Juda-Rezler 2010). The adopted models predicted the bias (mean bias (MB) and normal mean bias (NMB)), the error (root mean square error (RMSE)) and the coefficient of determination $\left(R^{2}\right)$.

\subsection{Spatial variograms modelling}

Spatial modelling was adopted in the present study owing to its robustness with the observed data that were present over each equal interval of the spatial variogram. In general, many functions were adopted to perform the variogram modelling; however, in the present study, some selected functions were chosen (Kanevski et al. 2009). The 
mathematical expressions of these functions along with the functionalities are described below:

$$
\gamma(h)=\left\{\begin{array}{l}
0, h=0 \\
c_{0}, h \neq 0 .
\end{array}\right.
$$

The mathematical expression for the pure nugget model is given in equation (5). However, this specific model does not reflect the spatial correlations and hence the interpolation process loses its significance and predicts only the mean value. Thus, the fracture of this model is rectified by the spherical model in equation (6). The function of the model is described below:

$$
\gamma(h)= \begin{cases}c_{0}+c\left(\frac{3 h}{2 a}-\frac{1}{2}\left(\frac{h}{a}\right)^{3}\right), & \text { if }|h| \leq a, \\ c_{0}+c, & \text { if }|h|>a,\end{cases}
$$

where $\left(c_{0}+c\right)$ is sill and $a$ is the range of correlation. The spherical model has a linear behaviour near the origin and its RF is continuous but not differentiable. Similarly, when the sill reaches zero, it is continuous but not differentiable. The constraint here is that the statistical variance of the function should be maintained even though the sill approaches the zero derivative.

The Gaussian model is adopted to overcome the differentiable issue faced by the previous function. The expression of the model is presented below in equation (7):

$$
\gamma(h)=c_{0}+c\left(1-\exp \left(\frac{-h^{2}}{a^{2}}\right)\right),
$$

where $a$ is an efficient radius of correlation and this model is suitable for processing the data with smooth behaviour of functions at short distances.

In some instance, this Gaussian model displays a nugget effect and is considered as an error of measurement; hence, the role of the exponential model (equation 8) is necessary. The function of the model is presented below:

$$
\gamma(h)= \begin{cases}0, & h=0 \\ c_{0}+\left(c-c_{0}\right)\left(1-\exp \left(\frac{-h}{a}\right)\right), & h \neq 0\end{cases}
$$

where $a$ is an effect of the radius of correlation, and at this distance, the variogram reaches $95 \%$ of the sill.

Finally, the power model (equation 9) was adopted to maximise the distance of the variogram. The expression of the model is written as

$$
\gamma(h)= \begin{cases}0, & h=0 \\ c h^{\lambda}, & 0 \leq \lambda \leq 2, h \neq 0 .\end{cases}
$$

It is to be noted that in all these models, sill $(c)$ can be only positive.

\section{Results and discussion}

\subsection{Black carbon emission and its distribution in the $X$ area}

The black carbon (BC) concentration in the fumes emitted from visible smoking vents and surface cracks in both the central and peripheral $\mathrm{X}$ areas are shown in figure 5. This includes 10 major vents with different intensities of fumes and fire zones along with the condensation of oil in and around the outer surface of spots. The overall average BC concentration was found to be $12.54 \mu \mathrm{g} \mathrm{m}^{-3}$. The significant variation in $\mathrm{BC}$ concentrations at different sites is attributed to the percentage of carbon content in that specific coal, the ventilation condition and the varied spontaneous combustion. The overall average discharge velocity at the crack is $\sim 1.9 \mathrm{~m} \mathrm{~s}^{-1}$ and ranges between 0.6 and $2.0 \mathrm{~m} \mathrm{~s}^{-1}$. A proportionate correlation was observed between $\mathrm{BC}$ with ambient and that with smoke fumes. The nearby temperature of the surface cracks and vents was found to be $48 \pm 9^{\circ} \mathrm{C}$.

The emission of fumes from the burning coal that could be correlated to the coal mineralisation (Stracher 2011) process is shown in figure 1. The underground coal seam fire produces numerous burnt and unburnt gases as a process of coal thermal decomposition, resulting in the formation of cracks and vents. In reality, huge portions of coal seam fires of this locality were smouldered with a high possibility of flaring when in contact with an oxygen-rich condition (Rein 2011). Thus, the continuous emission of $\mathrm{BC}$ is attributed to both smouldering and open fire conditions. A large open flame spot capable of discharging strong black smoke was seen at the circumference of the central part of the $\mathrm{X}$ area. Furthermore, in the nucleus of the $\mathrm{X}$ area, there were also spots with an intense whitish flame visible only at night.

Figure 6 provides the $\mathrm{BC}$ concentrations of the whole $\mathrm{X}$ area where the underground coal seam fire is prevalent. This distribution pattern reveals the various contours and topography of the study area, and this includes the complex terrain of 


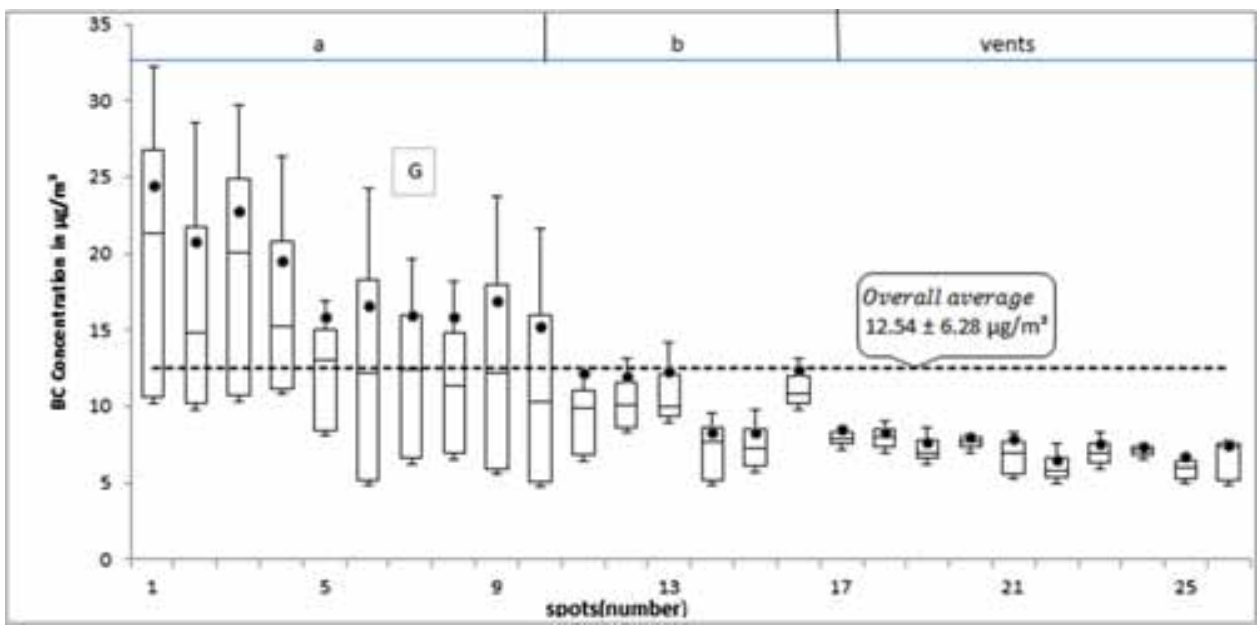

Figure 5. Distribution pattern of $\mathrm{BC}$ concentration at cracks ( $\mathbf{a}$ and $\mathbf{b}$ ) and vents in the central $\mathrm{X}$ area.

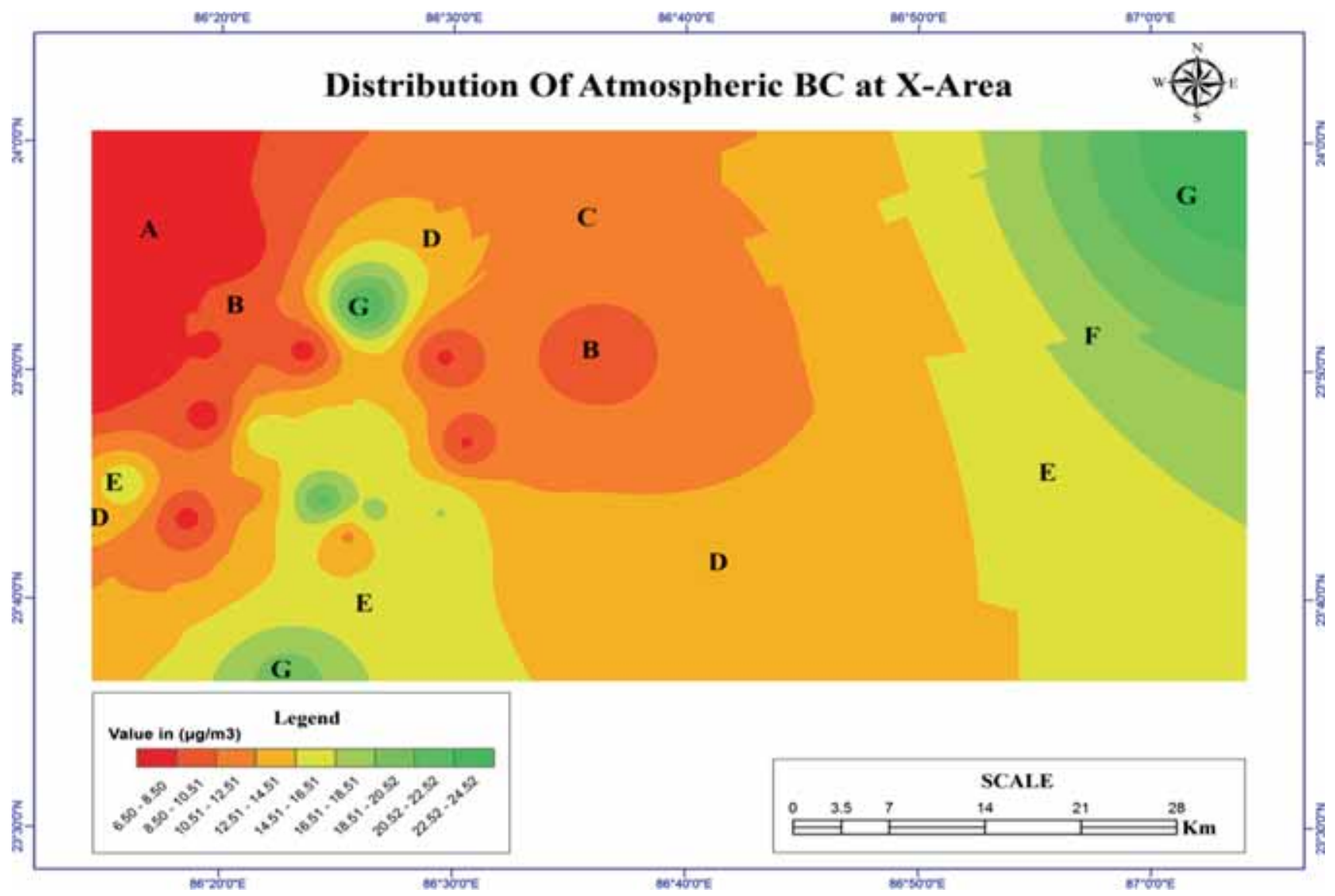

Figure 6. BC distribution near the atmospheric surface of the $\mathrm{X}$ area (underground seam fire).

the earth surface, strictness and junctures of the underground coal seam fire. The orange bent band that stretched from the northwest to the southeast and twisted west in the centre (see D contour in figure 6) is a major trench that separates the central and the peripheral zones within the $\mathrm{X}$ area. The green contour $\mathrm{G}$ is designated as a hot spot owing to the maximum number of cracks and vents. Thus, this predominant presence of vents and cracks advocates the possibility of a strong coal seam fire smouldering beneath it. The near surface $\mathrm{BC}$ concentration ranged between 12.0 and $15.0 \mu \mathrm{g} \mathrm{m}^{-3}$, with an average value of $12.54 \mu \mathrm{g}$ $\mathrm{m}^{-3}$. The observed value was attributed to the spontaneous release of fumes from mine cracks and vents. In the contour $\mathrm{F}$, insignificant cracks and 


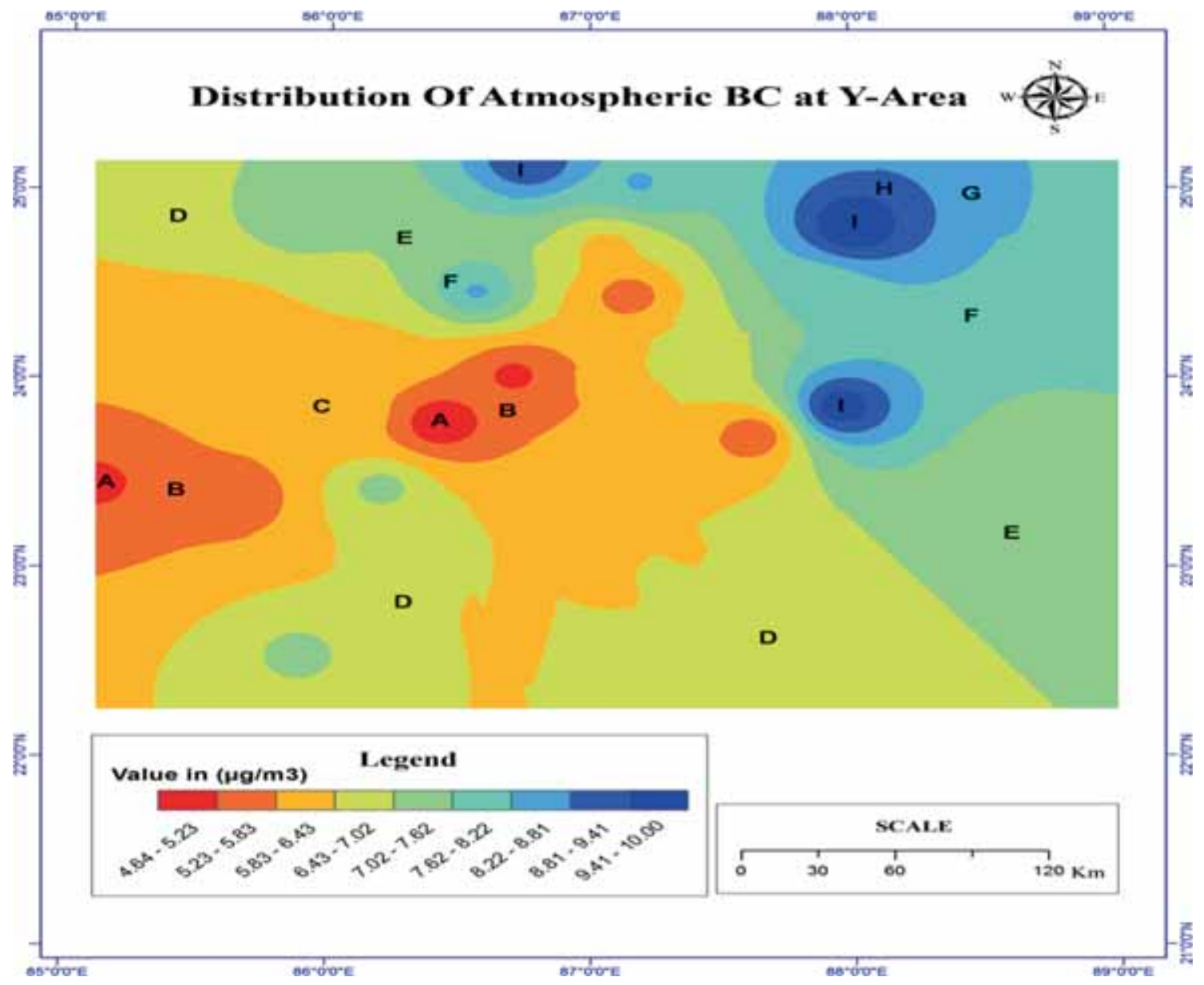

Figure 7. BC distribution near the atmospheric surface of the $\mathrm{Y}$ area.

vents were observed; however, the concentration of atmospheric BC surged to $21.0 \mu \mathrm{g} \mathrm{m}^{-3}$ from 18.0 $\mu \mathrm{g} \mathrm{m}^{-3}$. The $\mathrm{G}$ contour at the corner of the southeast central area is the locale with a huge coal pillar and open flame combustion, releasing strong black smoke that contributes to the highest near-surface BC concentration $\left(>21.0 \mu \mathrm{g} \mathrm{m} \mathrm{m}^{-3}\right)$. The level of $\mathrm{BC}$ discharged by the vent area was higher as it was associated by an open flame site (smaller than the vent). From figure 5, it is evident that the concentration of $\mathrm{BC}$ near the mine surface atmosphere of cracks and vents had highly escalated from ambient levels.

The in-situ concentration of $\mathrm{BC}$ at open flame sites was measured by restricting the high amount of heat liberated, and the network mapping around the EFG contour reflects the condition. On comparing contour $\mathrm{G}$ with $\mathrm{E}$ with regard to the concentration of $\mathrm{BC}$ near the surface atmosphere, $\mathrm{G}$ is $\sim 1.5$ times higher than $\mathrm{E}$, suggesting that the concentration of $\mathrm{BC}$ at the open flame site was greater than that at the cracks and vents (see figure 6). In general, the smouldering takes place prior to the open flame combustion and, hence, the present observations can be correlated to the percentage of carbon content. In the Indian scenario, a minor portion of coal seam undergoes flaming combustion, whereas the rest of the major portion endures smouldering. This critical scenario creates substantial complication in calculating the inventory for $\mathrm{BC}$ emission from the seam fire. Thus, the smouldering:flaming ratio requires a comprehensive calculation for $\mathrm{BC}$ emission. Moreover, due to the safety and potential hazard involved in the measurement of the actual amount of BC concentration, a flux at the open flame site is highly impossible.

The atmospheric BC concentration demonstrates the peripheral complex of the studied X area spanning from the north to west as shown in figure 6 . The highest level of $\mathrm{BC}$ in the northernmost terrain was in the $\mathrm{C}$ contour of the peripheral complex and ranged from 11.0 to $13.0 \mu \mathrm{g} \mathrm{m} \mathrm{m}^{-3}$, whereas the $\mathrm{A}$ and $\mathrm{B}$ of the same complex ranged from 


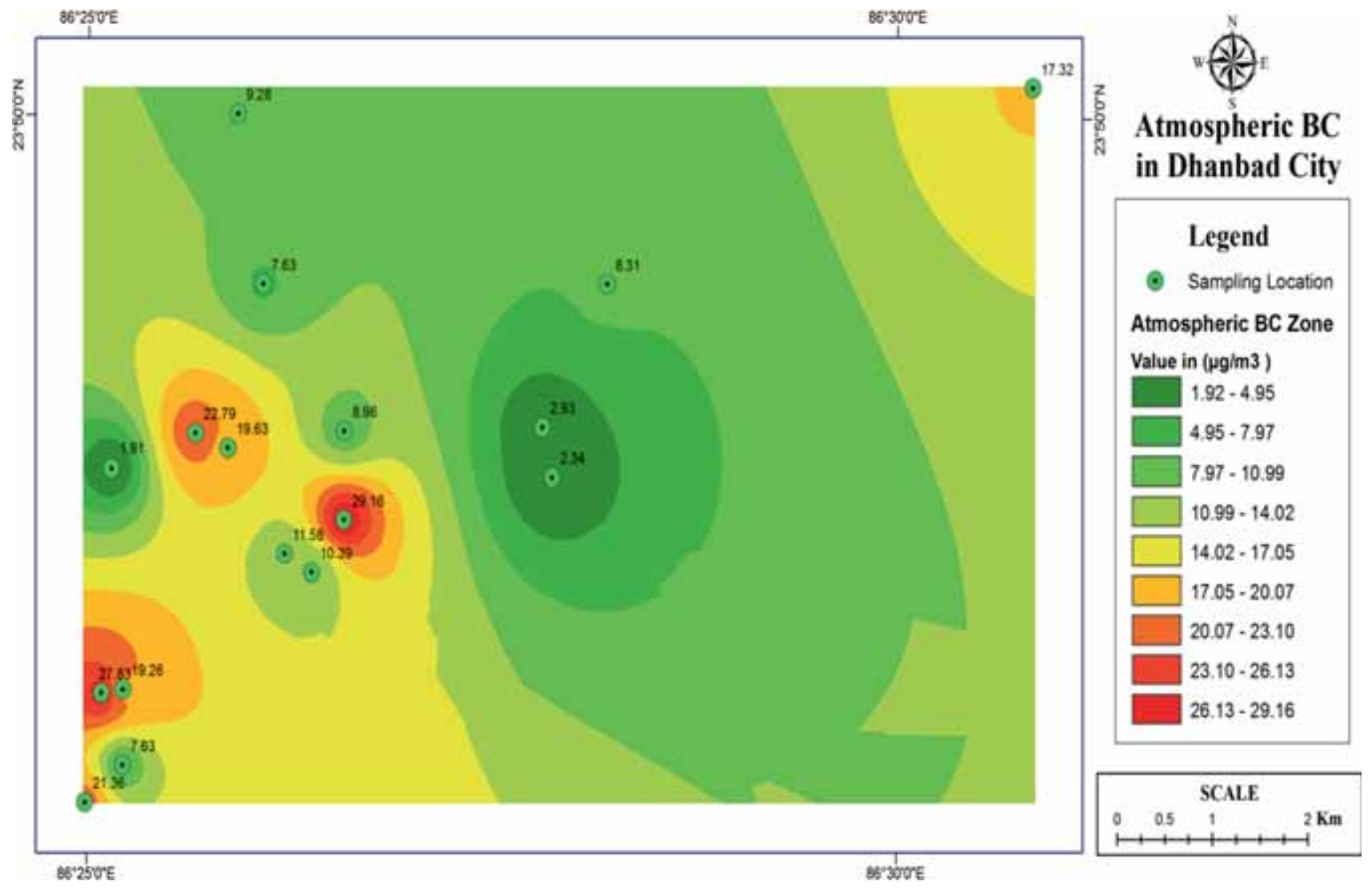

Figure 8. BC distribution near the atmospheric surface of the urban $\mathrm{Z}$ area.

6.0 to 9.0 and 9.0 to $11.0 \mu \mathrm{g} \mathrm{m} \mathrm{m}^{-3}$, respectively. The lower concentration in the peripheral complex was due to the movement of the wind towards the southeast, which thereby would have played an important role in the transportation of BC. The inconsistency between the gradient and the contour also has an influence on $\mathrm{BC}$ dispersion. The $\mathrm{C}$ contour had a flattened geometry, covered with rocks and soil in the entire site, while A and $\mathrm{B}$ also resembled a similar flattened geometry, comprising a surface with coal storage, overburden and hardened soil for a newly built haul road platform. Contour B housed a workshop with all the spare parts and construction materials spread in and around. The top surface of contour B was covered with sands, overburden, stones and wreckage, by-products derived from fire project (abandoned mine). This, in contrast to terrain surface filling, would result in the remission of BC. Moreover, the types of terrain and the exposure time of $\mathrm{BC}$ at each zone also exhibit a similar sequence. The $\mathrm{C}$ contour has a calm surface without any miningrelated activities and hence experiences stronger deposition, or else the newly built haul road platform in contour A receives the least deposition. Hence, the profile of the peripheral complex on the basis of terrain type becomes a critical parameter for both the emission and reemission of $\mathrm{BC}$.

Contour D, located in the eastern direction between the peripheral and the central complexes of the X area, consists of a deep trench of $4 \mathrm{~m}$, clearly isolating the affected and unaffected coal seams. The walls of the trench are made up of plain silts and rocks aiding in the reduction of the reemission flux of BC. There is no open burning or smoking activity reported inside the trench and hence the inner walls of the trench measure the ambient and surface temperature. From figure 5, it is obvious that the $\mathrm{BC}$ concentration at the close vicinity of firing contours $\mathrm{C}$ and $\mathrm{D}$ are at the same level and is close to the concentration as measured in ambient air of that locality. This inference is attributed to the presence of irregular terrain conditions and poor dispersion of high concentration $\mathrm{BC}$ over this zone.

\subsection{BC emission and its distribution in the $Y$ area}

The overall BC near the surface atmosphere is illustrated in figure 7 and it is clear that it is distributed evenly in the $\mathrm{Y}$ area with an average concentration of $6.90 \mu \mathrm{g} \mathrm{m} \mathrm{m}^{-3}$. This observation 

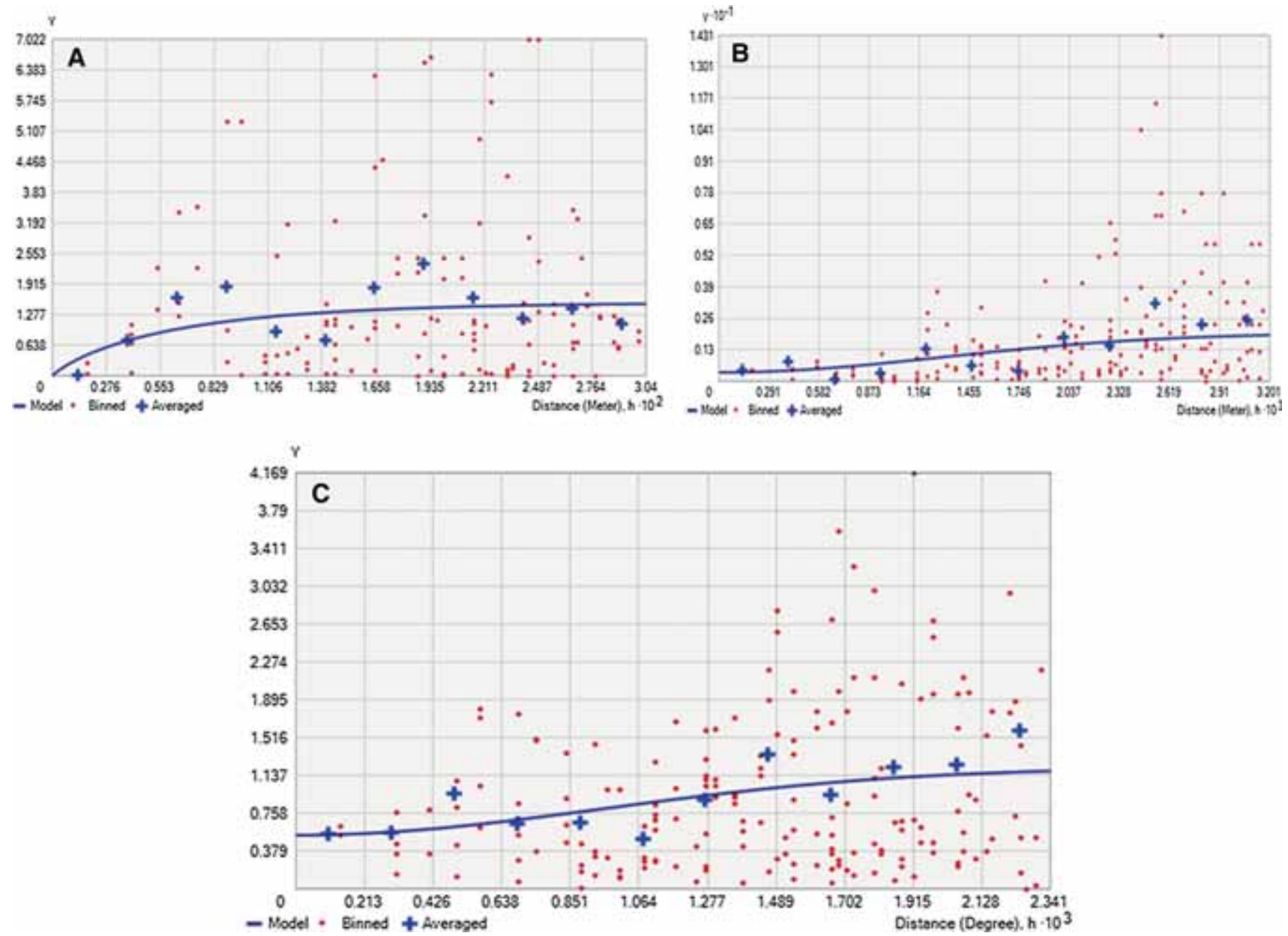

Figure 9. Semivariogram plot (variogram vs. distance) of the studied (a) X area; (b) Y area and (c) Z area.

Table 4. Hourly BC concentration descriptive statistics, $\mu g \mathrm{~m}^{-3}$.

\begin{tabular}{llllllllrr}
\hline & $N^{*}$ & \multicolumn{1}{c}{ Mean $(95 \% \mathrm{CI})$} & SD & SE & Min & Median & Max & P.95 & Skewness \\
\hline X area & 468 & $12.56(11.98-13.14)$ & 6.38 & 0.294 & 5.10 & 9.905 & 29.97 & 26.45 & 1.14 \\
Y area & 266 & $04.14(4.00-4.27)$ & 1.13 & 0.069 & 1.45 & 4.11 & 9.83 & 6.49 & 1.92 \\
Z area & 360 & $04.38(4.17-4.60)$ & 2.06 & 0.108 & 0.51 & 4.42 & 8.98 & 7.11 & -0.42 \\
\hline
\end{tabular}

*Number of samples.

is accredited to the fact that the fire in the underground coal seam is mostly burnt. Furthermore, this area is dominated by smouldering activity with a minor emission of BC through surface vents rather than open flames as seen in the $\mathrm{X}$ area. The area in the northeastern boundary shows the maximum concentration of $\mathrm{BC}\left(8.3-10.0 \mu \mathrm{g} \mathrm{m}^{-3}\right)$ and hence a consistent quantity of heavy fumes can be experienced. The highest level of atmospheric $\mathrm{BC}$ with discrete distribution was reported in the western boundary due to the presence of cracks and vents. This inconsistency in BC distribution recommends the occurrence of coal seam fires in the $\mathrm{Y}$ area as independent and is not similar to that in the $\mathrm{X}$ area where a different type of ecological restoration development procedure was implemented.

The concentration of BC near the mine surface atmosphere of the peripheral and central complexes of the $\mathrm{X}$ area is shown in figure 6 and the $\mathrm{Y}$ area in figure 7 , respectively. The average $\mathrm{BC}$ concentration in the near surface atmosphere of the central and peripheral complexes of the $\mathrm{X}$ area was recorded at $21.0 \mu \mathrm{g} \mathrm{m}^{-3}\left(17.0-25.0 \mu \mathrm{g} \mathrm{m}^{-3}\right)$ and $12.0 \mu \mathrm{g} \mathrm{m}^{-3}\left(6.50-17.0 \mu \mathrm{g} \mathrm{m}^{-3}\right)$, respectively. Whereas the average $\mathrm{BC}$ concentration in the $\mathrm{Y}$ area was found to be $7.0 \mu \mathrm{g} \mathrm{m} \mathrm{m}^{-3}(4.0-10.0 \mu \mathrm{g}$ $\mathrm{m}^{-3}$ ), which is one-third time lower than that of 
Table 5. Goodness-of-fit for three data sets based on hourly BC concentration.

\begin{tabular}{|c|c|c|c|c|c|c|c|}
\hline & $\begin{array}{c}\lambda_{k} \\
\text { (dimensionless) }\end{array}$ & $\begin{array}{c}A^{2} \\
\text { (dimensionless) }\end{array}$ & $\begin{array}{c}P \text { value } \\
(\text { dimensionless })\end{array}$ & $\begin{array}{c}\mathrm{MB} \\
\left(\mu \mathrm{g} \mathrm{m}^{-3}\right)\end{array}$ & $\begin{array}{c}\mathrm{NMB} \\
(\%)\end{array}$ & $\begin{array}{l}\text { RMSE } \\
\left(\mu \mathrm{g} \mathrm{m}^{-3}\right)\end{array}$ & $\begin{array}{c}R^{2} \\
\text { (dimensionless) }\end{array}$ \\
\hline \multicolumn{8}{|l|}{$Z$ area } \\
\hline \multicolumn{8}{|l|}{$N=360$} \\
\hline Lognormal & 0.327 & 57.015 & 0 & 0.008 & 16.1 & 0.103 & 0.85 \\
\hline Gamma & 0.203 & 107.69 & 0 & 0.000428 & 0.0801 & 0.08 & 0.93 \\
\hline Weibull & 0.217 & 27.37 & 0 & -0.00143 & -0.279 & 0.07 & 0.92 \\
\hline \multicolumn{8}{|l|}{$X$ area } \\
\hline \multicolumn{8}{|l|}{$N=468$} \\
\hline Lognormal & 0.106 & 8.53 & 0.00004 & 0.000619 & 0.129 & 0.06 & 0.96 \\
\hline Gamma & 0.113 & 10.69 & 0.000011 & -0.00625 & -1.289 & 0.064 & 0.95 \\
\hline Weibull & 0.14 & 16.86 & 0 & 0.007932 & 1.7136 & 0.085 & 0.93 \\
\hline \multicolumn{8}{|l|}{$Y$ area } \\
\hline \multicolumn{8}{|l|}{$N=266$} \\
\hline Lognormal & 0.267 & 64.71 & 0 & 0.00084 & 0.167 & 0.0773 & 0.87 \\
\hline Gamma & 0.117 & 12.4 & 0.00001 & -0.00021 & -0.042 & 0.08 & 0.86 \\
\hline Weibull & 0.169 & 18.31 & 0 & -0.0032 & -0.697 & 0.09 & 0.84 \\
\hline
\end{tabular}

the $\mathrm{X}$ area. However, the obtained results clarify that the near the surface atmospheric BC concentration in both areas is much higher than that in the background level $\left(1.70-3.30 \mu \mathrm{g} \mathrm{m}^{-3}\right)$, which indicates the transportation of $\mathrm{BC}$ through a point source.

\section{$4.3 B C$ distribution in the $Z$ area (urban setting)}

The $\mathrm{BC}$ concentration and its distribution patterns near the surface atmosphere in the urban area of Dhanbad are illustrated in figure 8. The total average was $13.43 \mu \mathrm{g} \mathrm{m}^{-3}\left(1.91-29.16 \mu \mathrm{g} \mathrm{m}^{-3}\right)$, which is three times more than that of a city (Pune, India, $4.1 \mu \mathrm{g} \mathrm{m}^{-3}$ ) with rapid industrialised activities and twice than that of a city (Bhubaneswar, India, $5.2 \mu \mathrm{g} \mathrm{m}^{-3}$ ) with intermediate industrial activities (Safai et al. 2007; Das 2010). The major anthropogenic sources for its concentration in the studied and compared cities include vehicular emission, industrial emission, domestic coal burning and thermal power plants (Safai et al. 2007; Das 2010). In the present study area, the atmospheric BC level may also share some similar sources; however, the presence of a significant amount of $\mathrm{BC}$ is attributed to the emission from the coal seam fire. The concentration of $\mathrm{BC}$ from the firing area to the urban area is shown in figure 8. The figure reveals an uneven distribution in the central area and is due to the strong association with urban activities such as vehicle emissions and domestic coal firings. Such a situation of coal seam fire to the proximity of the urban population is not only limited to the present study area, but it is the most common scenario of the nation.

\subsection{Variogram analysis}

The characterisation studies of the performed spatial correlations are shown in figure 9. The predicted semivariogram of the $\mathrm{X}$ area clearly predicts that the most modelled data follow the typical characteristic trend of the variogram with a minor deviation. However, in the $\mathrm{Y}$ area, the sill values are negligible, indicating a poor spread of the observed data over the predicted ones, while in the $\mathrm{Z}$ area, the average value of the observed and the modelled data follow an identical trend. The obtained kriging models for the respective areas are shown in figures S5-S7. These further substantiated the semivariogram model through the spatial variation of the studied $\mathrm{BC}$ concentration over the distance. A non-uniform and uneven distribution was predicted for all studied areas due to the fluctuating emission of the $\mathrm{BC}$ concentration.

\subsection{Descriptive statistics}

The 1-hr average concentrations of BC with its descriptive statistics for the studied sampling sites are shown in table 4 . The 1-hr mean BC concentration of the studied areas ranged as follows: $5.10-29.97 \mu \mathrm{g} \mathrm{m}^{-3}$ for the $\mathrm{X}$ area, $1.45-9.83$ $\mu \mathrm{g} \mathrm{m}^{-3}$ for the $\mathrm{Y}$ area and $0.51-8.98 \mu \mathrm{g} \mathrm{m}^{-3}$ for the $\mathrm{Z}$ area, respectively. In the urban $(\mathrm{Z})$ area, $\mathrm{BC}$ measurements included background concentrations 

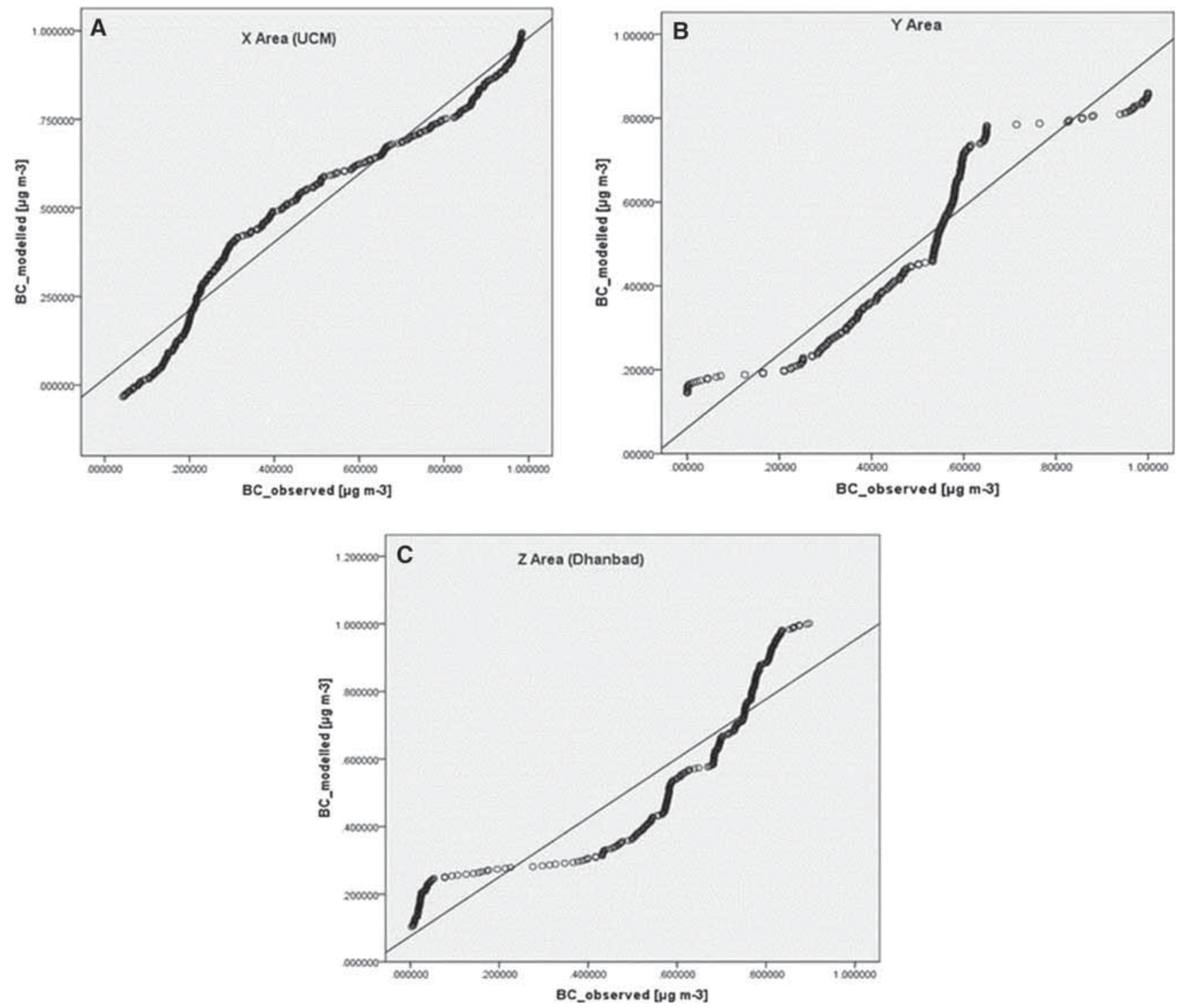

Figure 10. Quantile-quantile plots for the distribution of empirical data, with BC modelled by lognormal distribution.

emitted from automobiles and household; furthermore, the adverse meteorological conditions also impend the dispersion of pollutants.

\subsection{Statistical distribution analysis}

The experimental reliability of the obtained BC of the studied area was modelled with continuous probability distribution functions employing lognormal, gamma and Weibull (Georgopoulous and Seinfeld 1982; Kao and Friedlander 1994; Rumburg et al. 2001; Aleksandropoulou et al. 2012). It is not realistic to attain an appropriate overlap among observed data and model; however, we endeavoured to validate the practical inconsistencies among modelled and observed values. A summary of the performance indicators, such as bias, error, coefficient of determination and Anderson-Darling and Kolmogorov-Smirnov statistics, is presented in table 5 .

In all three datasets, the EDF was compared with the estimated parameters. The critical value for the $\lambda_{k}$ is 1.36 at a 0.05 level of significance. According to the Kolmogorov and Smirnov test, the distribution was consistent, but the $A^{2}$ indicator showed poor coordinance. At the $\alpha=0.01$ level of significance, the statistic is insignificant, and only in the $\mathrm{X}$ area, the lognormal distribution is favourable, while in the remaining areas, the $A^{2}$ is the highest with the worst fit.

As $\lambda_{k}$ and $A^{2}$ statistics show the best fit for the lognormal distribution in the $\mathrm{X}$ area, further analysis was also performed to fit the Weibull and gamma distributions which are shown in 
table 5 . The normal mean bias and the mean bias are positive in the lognormal case. This showed that the cumulative distribution of the $\mathrm{BC}$ concentration marginally estimated the probability of exceedance. The absolute RMSE value ranged from $0.05 \mu \mathrm{g} \mathrm{m} \mathrm{m}^{-3}$ (X area) to $0.10 \mu \mathrm{g} \mathrm{m} \mathrm{m}^{-3}$ ( $\mathrm{Z}$ area). The coefficient of determination $\left(R^{2}\right)$ measured the linear correlation between the modelled and observed data. High values were obtained for the lognormal model in the $\mathrm{X}$ and $\mathrm{Y}$ areas; however, all adopted models well supported the $\mathrm{X}$ area. Figure 10 represents the BC concentration modelled by quantile-quantile ( $\mathrm{Q}-\mathrm{Q})$ plots of the lognormal distributions vs. the observed data. The obtained $\mathrm{Q}-\mathrm{Q}$ plot further inspects the pattern of interference among the observed and the predicted results. The plot substantiates the linearity of the $\mathrm{X}$ area (figure 10a), whereas it overpredicted the values of the $\mathrm{Y}$ and $\mathrm{Z}$ areas (figure $10 \mathrm{~b}$ and $\mathrm{c}$ ), resulting in a deprived $R^{2}$ value.

\section{Conclusions}

$\mathrm{BC}$ aerosol from natural coal seam fire and its distribution throughout the mining and residential areas were clearly studied and mapped. The investigation confirmed that the concentration of $\mathrm{BC}$ does not reach the peak not only for the fire zone but a similar condition was observed at the surface exit. The study revealed the escalation of the overall average concentration of $\mathrm{BC}$ in the near surface atmosphere of the underground seam fire area. Furthermore, the continuous anthropogenic activities in the perimeter of the $\mathrm{X}$ area contributed to the increment of $\mathrm{BC}$ aerosol and, consequently, raised the concern of occupational health. The BC concentration in Dhanbad city reached a much higher level than that in any other similar urban areas (e.g., Kolkata, Bhubaneswar, Pune) of the nation. The study clearly presented the adverse contribution of the coal seam fire to national air quality. Overall, the present findings elucidate the significance of BC emission from an open coal seam fire.

\section{Acknowledgement}

The authors are grateful to Mr Subhendu Mondal, Department of Applied Geophysics, for his assistance with ArcMap.

\section{References}

Aleksandropoulou V, Eleftheriadis K, Diapouli E, Torseth $\mathrm{K}$ and Lazaridis M 2012 Assessing $\mathrm{PM}_{10}$ source reduction in urban agglomerations for air quality compliance; J. Environ. Monit. 14 266-278.

Banks D E, Wang M L and Lapp N L 1998 Respiratory health effects of open cast coal mining: A cross sectional study of current workers; Occup. Environ. Med. 55(4) 287-288.

BCCL 2008 Master plan for dealing with fire, subsidence and rehabilitation in the leasehold of $B C C L$; Bharat Coking Coal Limited, Dhanbad, India.

Bell F G, Bullock S E T, Hälbich T F J and Lindsay P 2001 Environmental impacts associated with an abandoned mine in the Witbank Coalfield, South Africa; Int. J. Coal Geol. 45 195-216.

Bond T C, Doherty S J, Fahey D W, Forster P M, Berntsen T, DeAngelo B J, Flanner M G, Ghan S, Kaercher B, Koch D, Kinne S, Kondo Y, Quinn P K, Sarofim M C, Schultz M G, Schulz M, Venkataraman C, Zhang H, Zhang S, Bellouin N, Guttikunda S K, Hopke P K, Jacobson M Z, Kaiser J W, Klimont Z, Lohmann U, Schwarz J P, Shindell D, Storelvmo T, Warren S G and Zender C S 2013 Bounding the role of black carbon in the climate system: A scientific assessment; J. Geophys. Res. 118 5380-5552.

Census of India 2011 Population data; Office of the Registrar General \& Census Commissioner, India. http://www. dataforall.org/dashboard/censusinfoindia_pca/, accessed 30 December 2016.

Christian R T, Nelson J B, Cody T E, Larson E and Bingham E 1979 Coal workers' pneumoconiosis: In vitro study of the chemical composition and particle size as causes of the toxic effects of coal; Environ. Res. 20(2) 358-365.

Cooke W F and Wilson J N 1996 A global black carbon aerosol model; J. Geophys. Res. 101 19395-19409.

D'Agostino R B and Stephens M A 1986 Goodness-of-fit techniques; Marcel Dekker, New York.

Das 2010 Aerosol characteristics over Bhubaneswar; ARFI \& ICARB Scientific Progress Report ISRO-GBP, India, $52-54$.

Ellyett C D and Fleming A W 1974 Thermal infrared imagery of the burning mountain coal fire; Remote Sens. Environ. 3 79-86.

Finkelman R B, Orem W, Castranova V, Tatu C A, Belkin H, Zheng B, Lerch H E, Maharaj S V and Bates A L 2002 Health impacts of coal and coal use: Possible solutions; Int. J. Coal Geol. 50(1-4) 425-443.

Georgopoulous P G and Seinfeld J H 1982 Statistical distributions of air pollutant concentrations; Environ. Sci. Technol. 16 401A-416A, https://doi.org/10.1021/ es00101a727.

Heffern E L and Coates D A 2004 Geologic history of natural coal-bed fires, Powder River basin, USA; Int. J. Coal Geol. 59 25-47.

Hendryx M 2009 Mortality from heart, respiratory and kidney disease in coal mining areas of Appalachia; Int. Arch. Occup. Environ. Health 82 243-249.

Hendryx M and Ahern M 2008 Relations between health indicators and residential proximity to coal mining in West Virginia; Am. J. Publ. Health 98 669-671. 
Highwood E J and Kinnersley R P 2006 When smoke gets in our eyes: The multiple impacts of atmospheric black carbon on climate, air quality and health; Environ. Int. 32 $560-566$

Juda-Rezler K 2010 New challenges in air quality and climate modeling; Arch. Environ. Prot. 36 3-28.

Kanevski M, Pozdnoukhov A and Timonin V 2009 Machine learning for spatial environmental data: Theory, applications and software (1st edn), EPFL Press, Switzerland, pp. $98-100$.

Kao A S and Friedlander S K 1994 Chemical signatures of the Los Angeles aerosol $\left(d_{\mathrm{p}}<3.5 \mathrm{~mm}\right) ;$ Aerosol Sci. Technol. 21 283-293.

Kuenzer C and Stracher G B 2012 Geomorphology of coal seam fires; Geomorphology 138 209-222.

Limacher D 1963 A propos de la formation de minéraux lors de la combustion des Charbons; Soc. Geol. Nord. Ann. $\mathbf{8 3}$ 287-288.

Liousse C, Penner J E, Chuang C, Walton J J, Eddleman H and Cachier H 1996 A global three-dimensional model study of carbonaceous aerosols; J. Geophys. Res. 101 19411-19432.

Magnier M 2012 India village fears being swallowed by the earth; http://articles.latimes.com/2012/jul/31/ world/la-fg-india-coal-fire-20120731, accessed on 5 June 2015.

Nolter M A and Vice D H 2004 Looking back at the Centralia coal fire: A synopsis of its present status; Int. J. Coal Geol. 59 99-106.

Parungo F, Nagamoto C, Zhou M-Y, Hansen A D A and Harris J 1994 Aeolian transport of aerosol black carbon from China to the ocean; Atmos. Environ. 28 3251-3260.

Penner J E, Eddleman H and Novakov T 1993 Towards the development of a global inventory for black carbon emissions; Atmos. Environ. A 27 1277-1295.

Pone J D N, Hein K A A, Stracher G B, Annegarn H J, Finkleman R B, Blake D R, McCormack J K and Schroeder P 2007 The spontaneous combustion of coal and its byproducts in the Witbank and Sasolburg coalfields of South Africa; Int. J. Coal Geol. 72 124-140.

Prakash A 2007 Coal fires in India; http://www2.gi.alaska. edu/ prakash/coalfires/coalfires.html, accessed 12 March 2015.

Rein G 2011 Smoldering combustion phenomena and coal fires; In: Coal and peat fires: A global perspective, volume 1: Coal-geology and combustion (eds) Glenn B Stracher, Anupma Prakash and Ellina V Sokol, Elsevier, Amsterdam, pp. 307-315.

Rumburg B, Alldredge R and Claiborn C 2001 Statistical distributions of particulate matter and the error associated with sampling frequency; Atmos. Environ. 35 2907-2920.

Safai P D, Kewat S, Praveen P S, Rao P S P, Momin G A, Ali K and Devara P C S 2007 Seasonal variation of black carbon aerosols over tropical urban city of Pune; India Atmos. Environ. 41 2699-2709.

Sarkar B, Mahanta B, Saikia K, Paul P and Singh G 2007 Geo-environmental quality assessment in Jharia coalfield, India, using multivariate statistics and geographic information system; Environ. Geol. 51 1177-1196.

Sharygin V V, Sokol E V and Belakovskii D I 2009 Fayalitesekaninaite paralava from the Ravat coal fire (central Tajikistan); Russ. Geol. Geophys. 50 703-721.

Singh A K and Mondal G C 2008 Chemical characterization of wet precipitation events and deposition of pollutants in coal mining region, India; J. Atmos. Chem. 59 $1-23$.

Stracher G B 2004 Coal fires burning around the world: A global catastrophe; Int. J. Coal Geol. 59 1-6.

Stracher G B 2011 Gas vent mineralization and coal combustion; In: Coal and peat fires: A global perspective, volume 1: Coal-geology and combustion (eds) Glenn B Stracher, Anupma Prakash and Ellina V Sokol, Elsevier, Amsterdam, pp. 135-153.

Stracher G B and Taylor T P 2004 Coal fires burning out of control around the world: Thermodynamic recipe for environmental catastrophe; Int. J. Coal Geol. 59 7-17.

Taraba B and Michalec Z 2011 Effect of longwall face advance rate on spontaneous heating process in the GOB area- CFD modelling; Fuel 90 2790-2797.

US Department of Energy 1993 The fire below; In: Spontaneous combustion in coal; Environmental Safety and Health Bulletin, Washington, DC, pp. 1-5.

Walker S 1999 Uncontrolled fires in coal and coal wastes, coal research; International Energy Agency, London, Great Britain, 73p.

Wang H, Nie L, Liu D, Gao M, Wang M and Hao Z 2015 Physico-chemical characterization and source tracking of black carbon at a suburban site in Beijing; J. Environ. Sci. 33 188-194.

Weglarczyk S 2010 Statistics in environmental engineering (in polish); Cracow University of Technology Publishing, Cracow.

Wolff G T 1981 Particulate elemental carbon in the atmosphere; J. Air. Pollut. Control. Assoc. 31 935-939, https://doi.org/10.1080/00022470.1981.10465298.

World Coal Association 2012 Coal facts 2012; https://www. worldcoal.org/coal-facts-2012, accessed on 15 September 2017.

Wu J-J and Liu X-C 2011 Risk assessment of underground coal fire development at regional scale; Int. J. Coal Geol. 86 87-94.

Yudovich E Y and Ketris M P 2005 Arsenic in coal: A review; Int. J. Coal Geol. 61 141-196.

Zhang X M, Kroonenberg S B and De Boer C B 2004 Dating of coal fires in Xinjiang, north-west China; Terr. Nova 16 $68-74$. 